\title{
The Determinants of the Level of Control in Foreign Market Entry of the Korean Healthcare Industry
}

\author{
Jae Hoon Hyun ${ }^{1^{*}}$ \\ ${ }^{1}$ Department of International Business, Hankuk University of Foreign Studies \\ 한국의료산업의 해외시장 진출 통제수준의 결정요인에 관한 연구 \\ 현재훈 ${ }^{*}$ \\ ${ }^{1}$ 한국외국어대학교 국제경영학과
}

\begin{abstract}
This study focuses on the internalization process of service sector, especially on the foreign market entry modes of Korean healthcare industry. The paper examined the effects of country and firm specific factors, and strategic elements of the industry on the selection of foreign market entry modes by using multiple regression analysis. The findings indicate that firms' global experience and documented strategic assets have significant effects on the high control organizational types in the selection of entry mode while the other determinants including size of the firm were found to be less significance. This study provides the academic implications to the subject of the internationalization of Asian service industry and the practical reference to this highly specialized soft service sector.

요 약 본 연구는 서비스 영역의 국제화, 특히 국내 의료산업의 해외진출 방식을 다중회귀분석 이용하여 국가와 기 업특유의 요인 및 전략적 인자가 해외시장 진출 방식을 결정하는데 어떠한 영향을 미치고 있는가를 분석하였다. 연구 의 결과 기존 해외시장에서의 경험과 체계화된 전략적 자산이 해외진출 방식의 결정에 있어 보다 높은 통제수준의 진입 방식을 결정하게 하는 요인으로 밝혀졌으며 기업의 규모와 같은 기업특유 요인들은 통계적으로 유의하지 않은 것으로 나타났다. 본 연구는 제조업에 비해 국제화의 정도가 낮은 수준에 머무르고 있는 아시아 서비스 산업의 해외 진출에 관한 이론적 틀을 제공하고 특히 특화된 소프트 산업으로서 의료산업의 향후 해외진출 방식 결정에 있어 동 기와 통제의 수준 간에 관한 실무적 함의를 제공하고 있다.
\end{abstract}

Key Words : Foreign Market Entry Mode, Green Field Investment, Healthcare Industry, Joint Venture, Strategic Alliance

\section{Introduction}

The development and globalization of the Korean healthcare industry has been delayed compared to that in other countries since it has been considered as public service limited to domestic market rather than private sector pursuing profits and voluntary globalization. Recent years witnessed the dramatic deregulations on the health industry which facilitated the room for the globalization. In addition, the external context has become favorable when the obstacles imposed on the industry among a number of developing countries have been reduced or disappeared. Considering the contextual significance, this study focuses on the globalization of the Korean healthcare industry with particular reference to the foreign market entry modes based on the theories on the

This work was supported by Hankuk University of Foreign Studies research fund of 2012.

${ }^{*}$ Corresponding Author : Jae Hoon Hyun(Hankuk University of Foreign Studies)

Tel: +82-31-330-4521 email: jhyun@hufs.ac.kr 
internationalization of the service industry.

Considering the differences even within the service industry, this study opted theoretical framework appropriate for the health industry and carefully selected variables affecting the modes of foreign market entry. Subsequently, the survey on the Korean healthcare industry has been given to examine the research question that if there are significant differences in effective variables for the foreign market entry modes.

\section{Theory and Hypothesis}

The theoretical debates related to the foreign market entry of the service industry have mainly placed the focus on whether the traditional approaches used for the manufacturing industry are also applicable for the service industry $[1,2,3]$ The service industry has asset specificity that the size of investment is relatively modest compared to the manufacturing industry $[3,4]$ and it is invisible-labor intensive and the production and consumption may not be separated [5,6] Selected service industries were examined such as the advertisement industry [1], equipment lease [2], financial sector [7,8], software [9], and hotel industry [10].

This study particularly pays attention to works of Contractor and Kundu [10] who developed syncretic theory which combined concepts from transaction costs theory, agency theory, corporate knowledge and organizational capability theories and examined the framework on the hotel sector. Considering the similarities between hotel and healthcare services and the benefits of comprehensiveness covering traditional approaches and recent attempts, this study exploited the framework of their study in developing variables and hypothesis $[11,12,3,10]$.

Wholly owned subsidiary and majority owned subsidiary are considered to be high control entry modes when minority owned subsidiary, contract, alliances, and market by means of export are categorized as low control mode [13]. In a case of soft service industry, export may not be opted, the health industry, however, may facilitate the mobility of foreign patients based on highly capital intensive character of the industry [14].

Hypotheses were developed based on the syncretic approach. Firstly, country specific variables such as country risks, cultural distance, and the degree of development were considered [2,15,12]. Secondly, firm specific variables are considered to have positive effects on high control entry modes. In this proposition, scale, global experience, and accumulated overseas knowledge might induce higher control entry mode $[3,16]$ while firms with less international experience have limited capacity to assess the oversea markets and tend to overvalue the risks which lead to low control entry modes $[15,3,17,18]$. Thirdly, this study also proposed that corporate strategy and control elements including quality control, documented strategic assets, $\mathrm{R} \& \mathrm{D}$ and training expenditure may positively affect firms to choose high control entry modes. Behavioral uncertainties related to the partner firms and monitoring opportunitism incurs costs and high control entry and organization may reduce the transaction costs cause the requirements of international cooperation are diminished $[19,20]$. In particular, this variable is highly applicable to the service industry because the specific characteristics of service industry such as heterogeneity and inseparability increase uncertainties and monitoring costs compared to any other industries. [10] suggested that documented strategic assets in the hotel industry provided ownership control regardless organizational types and structures and decreased limited rationality and opportunitism problems. In manufacturing industry, $R \& D$ expenditure against revenue implicitly represents corporate capacity and competitiveness. Profit surplus incurred based on competitive advantages and organizational capabilities are considered to be best exploited by high control entry modes and organization structures [15]. Expenditure on training and human resource development in the service industry to increase employees' knowledge and organizational capabilities were considered to be similar to those in manufacturing industry [10]. Increased internal organizational capabilities related to knowledge may lead to high control entry modes since the transfer of those internalized knowledge incurs high costs [12].

H1. Higher degree of country specific variables such as country risks, cultural distance, and the degree of development will induce healthcare firms to engage in high control entry modes. 
H2. Higher level of firms specific variables such as firm size and overseas experience will affect healthcare firms to engage in high control entry modes

H3. Corporate strategy and control elements such as quality control, documented strategic assets, R\&D expenditure will positively affect healthcare firms to engage in high control entry modes

\section{Analysis}

This study employed survey method together with data and information from secondary sources. Target respondents of the survey were Korean healthcare firms already have entered foreign markets or have planned to expand within the forthcoming years. Questionnaires are collected by means of email and telephone communication and 57 cases were analyzed using multiple regression. Country specific, firms specific, corporate strategy and control variables were examined for the credibility. The cronbach's alpha showed 0.63 for country specific variables, 0.94 for firm specific variables, and 0.86 for the corporate strategy and control variables.

[Table 1] Regression results: Country specific variables

\begin{tabular}{|l|r|r|r|r|}
\hline \multicolumn{1}{|c|}{ Variables } & \multicolumn{1}{c|}{$\mathrm{B}$} & \multicolumn{1}{c|}{$\beta$} & $\mathrm{t}$-value & \multicolumn{1}{c|}{$\mathrm{p}$} \\
\hline Constant & 3.772 & & 1.304 & .211 \\
\hline POLIS & -.049 & -.043 & -.150 & .882 \\
\hline INVR & .135 & .117 & .218 & .830 \\
\hline CONFIS & .399 & .373 & .929 & .367 \\
\hline PRIC & -.132 & -.114 & -.255 & .802 \\
\hline LOC & -1.183 & -.895 & -1.515 & .149 \\
\hline TRNS & .520 & .465 & 1.013 & .326 \\
\hline COMM & .776 & .737 & 1.095 & .290 \\
\hline ADPT & .504 & .462 & .704 & .492 \\
\hline CUL & -1.039 & -.995 & -2.049 & .057 \\
\hline & \multicolumn{1}{c|}{$\mathrm{R}$} & Adj. $\mathrm{R}$ & $\mathrm{F}$ & $\mathrm{P}$ \\
\hline & .398 & .259 & 1.174 & .373 \\
\hline
\end{tabular}

* $\mathrm{P}<0.05, * * \mathrm{P}<0.01$

POLIS: Political Stability, INVR: Ownership Control, CONFIS: Confiscation, PRIC: Price Control, LOC: Local Content Rules, TRNS: Capital Transfer, COMM: Communication, ADPT: Local Adaptability CUL: Cultural Differences

Firstly, multiple regression was employed to examine the relations between the foreign market entry modes and the country specific variables such as country risk, cultural distance, and the degree of development. The results show that country specific variables are insignificant as determinants for high control entry modes. This results imply that Korean health institutions are least affected by the host country status and risks. Hence, the first hypothesis is not statistically supported based on the results.

Secondly, the subsequent hypothesis was tested by examining the firm specific variables. Model fitness is considered to be appropriate as model $\mathrm{p}$ value shows 0.008 . The second hypothesis is partially supported as the variable, number of subsidiaries, is found out to be statistically significant as determinant affecting firms to enter the foreign market with high control modes.

[Table 2] Regression results: Firm specific variables

\begin{tabular}{|l|c|c|c|c|}
\hline \multicolumn{1}{|c|}{ Variables } & \multicolumn{1}{c|}{$\mathrm{B}$} & \multicolumn{1}{c|}{$\beta$} & $\mathrm{t}$-value & $\mathrm{p}$ \\
\hline Constant & .562 & & -.328 & .746 \\
\hline REV & .022 & .017 & .097 & .923 \\
\hline LENG & -.205 & -.145 & 0.535 & .597 \\
\hline NSUB & 1.143 & .715 & 2.669 & $.013^{*}$ \\
\hline & $\mathrm{R}$ & Adj. R & $\mathrm{F}$ & $\mathrm{P}$ \\
\hline & .358 & .284 & 4.838 & $.008^{* *}$ \\
\hline
\end{tabular}

* $\mathrm{P}<0.05, * * \mathrm{P}<0.01$

REV: Revenue, INVR: Length of Overseas Experience, NSUB: No of Subsidiaries

Thirdly, the corporate strategy and control variables are examined related to the effects of quality control, documented strategic assets, and R\&D and training expenditures on foreign market entry modes. The following table shows the result and the third hypothesis also partially supported as documented strategic assets only statistically supported as determinants for high control entry modes.

[Table 3] Regression results: Corporate strategy and control

\begin{tabular}{|l|c|c|c|c|}
\hline \multicolumn{1}{|c|}{ Variables } & $\mathrm{B}$ & \multicolumn{1}{c|}{$\beta$} & $\mathrm{t}$-value & $\mathrm{p}$ \\
\hline Constant & 4.758 & & 2.166 & 0.040 \\
\hline QC & -.369 & -.193 & -.878 & .388 \\
\hline DSA & .617 & .519 & 2.214 & $.036^{*}$ \\
\hline RDT & -.162 & .115 & -.627 & .537 \\
\hline & $\mathrm{R}$ & Adj. R & $\mathrm{F}$ & $\mathrm{P}$ \\
\hline & .385 & .255 & 1.418 & .257 \\
\hline
\end{tabular}

* $\mathrm{P}<0.05, * * \mathrm{P}<0.01$

QC: Quality Control, DSA: Documented Strategic Assets, RDT: R\&D and Training Expenditure 
Based on the results, $\mathrm{H} 2$ and $\mathrm{H} 3$ are partially supported whereas H 1 is not. When Korean health institutions consider foreign market entry, the greater their existing global experience and established documentations as strategic assets are the more they engage in the high control entry modes. The study of Contractor and Kundu [10] shows similar results regarding global experience and high control entry modes, although recent empirical studies could not support the thesis [18]. Host country related factors are less likely to affect the entry mode decisions.

\section{Implications and Conclusions}

This study employed the syncretic framework to examine the foreign market entry modes of Korean health service firms. The specific characteristics of the service industry have also been corporate into the framework. The particularities of healthcare industry as soft service compared traditional manufacturing industry derived by complex transaction costs and potential business partners considered and incorporated in to the analysis.

Based on the analysis, firms' prior global experience affects firms to opt high control entry modes which showed that Korean healthcare firms utilize overseas experience to effectively control and exploit specialized knowledge and management capabilities. In addition, documented strategic asset was also found to be significant factor as determinant for high control entry modes.

In case of the Korean health industry, only recent years regulations on the industry for overseas investment were liberalized, exogenous factors such as policies and government initiatives probably have affected the globalization of the industry to a certain extent. The variables considered in this study, therefore, were confined because it is difficult to include those exogenous factors which inevitable in the context of the Korean healthcare industry. The qualitative considerations and intuitions may be required for the integrated understanding of this particular context.

\section{References}

[1] Terpstra, Vern and Chwo-Ming Yu, "Determinants of foreign investment of US advertising agencies", Journal of International Business Studies, 19(1): 33-46, 1988. DOI: http://dx.doi.org/10.1057/palgrave.jibs.8490373

[2] Agarwal, Sanjeev and Sridhar N. Ramaswami "Choice of foreign market entry mode: Impact of ownership, location and internalization factors", Journal of International Business Studies, 23 (1): 1-27, 1992. DOI: http://dx.doi.org/10.1057/palgrave.jibs.8490257

[3] Erramilli, M. Krishna and Rao, C.P. "Choice of foreign market entry modes by service firms: role of market knowledge", Management International Review, 30(2): 135-51, 1990.

[4] Boddewyn, Jean J., and A.C. Perry, "Service Multinationals: Conceptualization, Measurement and Theory", Journal of International Business studies, 17(3): 41-57, 1986.

DOI: http://dx.doi.org/10.1057/palgrave.jibs.8490860

[5] Zeithaml V.A., Parasuraman A. and Berry L.L. "Problems and Strategies in Services Marketing", Journal of Marketing, 49, 33 - 46, 1985.

DOI: http://dx.doi.org/10.2307/1251563

[6] Ekeledo, Ikechi \& K. Sivakumar "Foreign Market Entry Mode Choice of Service Firms: A Contintency Perspective", Journal of the Academy of Marketing Science. 4: 274-292, 1998.

DOI: http://dx.doi.org/10.1177/0092070398264002

[7] Hellman, P. "The Internationalization of Finninsh Financial Service Companies", International Business Review, 5: 191-208, 1994.

DOI: http://dx.doi.org/10.1016/0969-5931(96)00005-4

[8] Sagari. S.B. "United States Foreign Direct Investment in The Banking Industry", Transnational Corporations, 1(3): 92-123, 1992.

[9] Brouthers, Keith D., Lance Eliot Brouthers and S. Werner, "Dunning's Eclectic Theory and the Smaller Firm: the Impact of Ownership and Locational Advantages on the Choice of Entry-modes in the Computer Software Industry", International Business Review, 5(4): 377-394, 1996.

DOI: http://dx.doi.org/10.1016/0969-5931(96)00019-4

[10] Contractor, Farok J., and Kundu, Sumit K. "Modal Choice in a World of Alliances: Analyzing Organizational Forms in the International Hotel Sector", Journal of International Business Studies, 29(2): 325-358, 1998. 
DOI: http://dx.doi.org/10.1057/palgrave.jibs.8490039

[11] Contractor, Farok J. "The composition of licensing fees and arrangements as a function of economic development of technology recipient nations", Journal of International Business Studies, 11(3): 47-62, 1990.

DOI: http://dx.doi.org/10.1057/palgrave.jibs.8490622

[12] Kim, W.Chan and and Peter Hwang "Global strategy and multinationals' entry mode choice", Journal of International Business Studies, 23(1): 29-53, 1992. DOI: http://dx.doi.org/10.1057/palgrave.jibs.8490258

[13] Anders Blomstermo, D. Deo Sharma, James Sallis, "Choice of foreign market entry mode in service firms", International Marketing Review, Vol. 23 Iss: 2, pp.211 - 229, 2006.

DOI: http://dx.doi.org/10.1108/02651330610660092

[14] Sampson, Gary P. and Richard H. Snape "Identifying the issues in trade in services", The World Economy, 8(2): 171-182, 1985.

DOI: http://dx.doi.org/10.1111/j.1467-9701.1985.tb00421.x

[15] Gatignon, Hubert and Anderson, Erin "Modes of foreign entry: a critical analysis", Journal of International Business Studies, 24(2): 1-26, 1986.

[16] Gomes-Casseres, B. "Control and performance of international joint ventures", Journal of International Business Studies, 20(2): 235-54, 1989.

DOI: http://dx.doi.org/10.1057/palgrave.jibs.8490359

[17] Chang, S.J. "International expansion strategy of Japanese firms: capability building through sequential entry", The Academy of Management Journal, 38(2): 383-407, 1995.

DOI: http://dx.doi.org/10.2307/256685

[18] Blomstermo, Anders and D.Deo Sharma. "Choice of foreign market entry mode in service firms", International Marketing Review, 23(2): 211-229, 2006. DOI: http://dx.doi.org/10.1108/02651330610660092

[19] Hill, Charles W.L. "Cooperation, opportunism, and the invisible hand: implications for transaction cost theory", Academy of Management Review, 15(3): 500-513, 1990.

DOI: http://dx.doi.org/10.5465/AMR.1990.4309111

DOI: http://dx.doi.org/10.2307/258020

[20] Williamson, Oliver E. "Comparative economic organization: the analysis of discrete structural alteratives'", Administrative Science Quarterly, 36: 269-296, 1991.

DOI: http://dx.doi.org/10.2307/2393356
Jae Hoon Hyun

[Regular member]

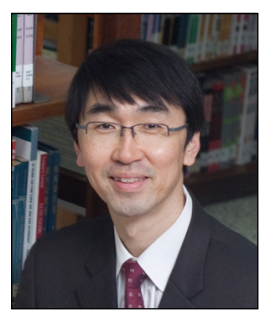

- Sept. 1997 : University of Sheffield, M.Phil.

- Jan. 2002 : University of Sheffield, Ph.D.

- Jan. $2002 \sim$ Aug. 2005 : Senior Consultant, LG CNS

- Sept. $2007 \sim$ current : Associate Professor, Hankuk Univ. of Foreign Studies, Dept. of International Business

$<$ Research Interests $>$

International Business, Foreign Direct Investment, Strategic Alliance, Open Innovation, 